\title{
The Views of Physical Education and Sports Teaching Instructors on Education in the COVID-19 Period
}

\author{
Şule Kırbaş ${ }^{1}$ \\ ${ }^{1}$ Physical Education and Sport Teacher Department, Faculty of Education, Amasya University, Amasya, Turkey \\ Correspondence: Şule Kırbaş, Physical Education and Sport Teacher Department, Faculty of Education, Amasya \\ University, Amasya, Turkey. E-mail: sulekirbas@gmail.com
}

Received: October 25, 2020 Accepted: November 26, 2020 Online Published: November 30, 2020

doi:10.5539/jel.v9n6p196 URL: https://doi.org/10.5539/jel.v9n6p196

\begin{abstract}
This study was conducted to determine the views of academicians regarding "The Views of Physical Education and Sports Teaching Instructors on Education in the Covid-19 Period". The study used the phenomenological design, which is among qualitative research designs.

The study group comprised 63 academicians carrying out duty in 21 different universities in Turkey during the 2019-2020 academic year. In line with the goal, the study was carried out with academicians who could contribute on voluntary basis. In order to determine the views of the academicians, a structured interview form was used. The interview form comprises four questions aiming to determine the necessity of distance education in the physical education area, which courses in the area can be given within the scope of distance education, possibility of teaching applied courses via distance education and problems they face in courses in the distance education process which has been put into effect compulsorily due to pandemic.

The interview form was presented to the opinion of two instructors in the educational sciences area who have carried out qualitative research and then expert opinion was received. The application was conducted by primarily reaching the aforementioned academicians via telephone interview between 1 June-27 July 2020 and conveying the questions via e-mail. The descriptive analysis technique was used in analysis of the data.

In the study $79 \%$ of the academicians stressed that applied courses should not be taught via distance education, while $52 \%$ stated that all theoretical courses could be taught via distance education. Examining the views of the academicians on the problems they faced in courses in the distance education process; $55 \%$ stated that the problems were associated with the system, $36 \%$ efficiency of the course, $30 \%$ inadequate student participation in the course, $21 \%$ inadequate student feedback, $21 \%$ evaluation, $19 \%$ inexperience about distance education and $17 \%$ lack of internet and computer opportunities in hometowns of students.

Considering the findings of the study integratedly; it is believed that teaching applied courses via distance education is inadequate and inefficient. Also it is possible to state that it may not be appropriate to teach theoretical courses via distance education, except when necessary.
\end{abstract}

Keywords: Covid-19, physical education and sports teaching, instructors, digital education

\section{Introduction}

A new outbreak caused by a new coronavirus, called COVID-19 by the World Health Organization (WHO) (Olmos-Gómez, 2020), began in China (Wuhan) in December 2019 and spread all over the world despite all the strategies implemented by the Chinese government (Tria, 2020). Three months after the pandemic started, more than 353,000 cases and 15,000 casualties were detected in all over the world on 23 March 2020 (Pavon \& Baeza, 2020). While the number of cases increased to $19,718,030$, the number of casualties reached 728,013 as of 10 August 2020 (WHO, 2019). Increasing numerical data is an indicator that the pandemic continues to pose a serious threat to the whole world and affects all sectors.

The future of the countries depends on the young generations that they will raise as knowledgeable, efficient, productive, in short, fully equipped. This qualification can only be gained through education. The main purpose of education is to bring individuals to the highest possible level of excellence (Alkan, Doğan, \& Sezgin, 1991).

However, since the second month of the pandemic, many countries around the world have temporarily closed 
their educational institutions in order to control the spread and reduce the infection. This has affected more than 1.2 billion students worldwide (UNESCO, 2020). Uncertainties during the pandemic process have also caused many disruptions in education. In order to ensure that education and training were not interrupted and completed with minimal damage, the process required online learning platforms to be offered to students, and teachers and students have to work from home (Crawford et al., 2020). These platforms are online learning platforms such as Google, Television broadcasts, guides, resources, video lessons, and live broadcast lessons (UNESCO, 2020).

It is an undeniable fact that teaching is an important profession and how important it is to train qualified teachers. Universities and especially education faculties have significant roles in educating qualified individuals. The quality of the professions should be considered as equivalent to the quality of education provided.

Quality is known to be the most essential factor in the development of the education system. Quality relates to the features expected from the products and services offered. The quality of education is expressed as the way and degree of achievement of the objectives and functions of education. Physical structure and equipment, human resources, financial resources, legislation, education programs, means of accessing information, school culture, and scientific, cultural, and sports activities are among the factors that determine the quality of education provided in Schools of Physical Education and Sports. High quality and quantity of these factors are important for shaping the student profile intended to be raised (Yildiz, 2007).

As in all over the world, education in Turkey has been negatively affected during the pandemic. The normal formal education process has had to leave its place to distance education. All universities with or without distance education infrastructure and staff trained in the field of distance education suddenly found themselves in this system. Obviously, the education system was caught off guard. Physical Education and Sports Departments in all universities have also tried to carry out their courses with distance education in this process. Although all courses are tried to be given, distance education has caused disruptions in the applied courses of the teacher candidates.

Physical education and sports teachers have very important responsibilities such as training healthy individuals, reducing the risk of obesity, raising athletes for the infrastructures of sports clubs, exploring and training athletes who will represent the country, as well as meeting the need for children to move and playing games. Therefore, the quality of physical education and sports teachers has become even more important today, when the importance of physical activities in society is increasing. In order for teachers to teach a subject, they must first know the subject themselves. Physical education teachers must first learn the skills they will teach in practice, both theoretically and practically, with active participation, so that they can teach. However, during the pandemic process, all the courses of the teacher candidates were tried to be carried out theoretically over the online system.

Previous studies stated that teachers' knowledge, interest, behavior, and personality are effective in the success of students in the education process (Filiz, 2004). As the teacher-student interaction is extremely important in terms of individual development in the education and training process, teachers must be addressed not only in all aspects of knowledge but in the training of individuals who have the equipment required by the age, who can continuously improve themselves and their environment, and who can see and evaluate the facts and events around them in a multifaceted manner. Especially in terms of education faculties, besides the theoretical knowledge, teacher candidates also have the opportunity to experience the methods and techniques on how to transfer that knowledge from the faculty member during the face-to-face training. During the pandemic process, education was insufficient not only at the point of learning information but also in terms of teaching the learned subject effectively and experiencing the right communication with the student. Developing educational institutions, increasing the quality of educators, and active participation of the individual in all stages of education is important for individuals to learn through education and to realize a developing society (Gökçe, 2004).

Considering that the pandemic continues as of August and will continue for a long time as stated by experts; By taking the "The Views of Physical Education and Sports Teaching Instructors on Education in the Covid-19 Period", the present research conducted to contribute to minimizing deficiencies and disruptions in an exceptional period such as the COVID-19 pandemic in the next academic year, to provide better quality education according to the conditions to have a more efficient process and to be better prepared for another crisis in the future. 


\section{Method}

\subsection{Research Design}

This research was conducted to determine the "The Views of Physical Education and Sports Teaching Instructors on Education in the Covid-19 Period". Phenomenological design, one of the qualitative research designs, was used in the study. The phenomenological research design focuses on situations that we are aware of but want to reach in-depth knowledge. The phenomenon can occur in ways such as experiences, orientations, trends, concepts, situations, and events around the world (Çiftçi, 2016). In the phenomenological design, it is aimed to reveal commonly used applications and to define and explain the opinions expressed by the research participants (Ersoy, 2014).

\subsection{Study Group}

The study group of the research consists of 63 academics working at 21 different universities in Turkey in the 2019-2020 academic year. Out of 63 academics consisting study group, 10 academics work at Afyon Kocatepe University, eight at Ağrı İbrahim Çeçen University, two at Amasya University, four at Atatürk University, one at Aydın Adnan Menderes University, one at Balıkesir University, one at Çanakkale Onsekiz Mart University, one at Adana Çukurova University, two at Kayseri Erciyes University, one at Erzincan Binali Yıldırım University, three at Elazığ Firat University, one at Isparta Süleyman Demirel University, three at İzmit Kocaeli University, one at Kahramanmaraş Sütçü İmam University, one at Niğde Ömer Halis Demir University, one at Samsun Ondokuz Mayıs University, eight at Ordu University, four at Denizli Pamukkale University, three at Sivas Cumhuriyet University, five at Tokat University, and two academics work at Zonguldak Bülent Ecevit University.

The research was conducted with academics who can contribute on a voluntary basis in line with its purpose.

\subsection{Data Gathering Tools and Data Gathering}

In this research, a structured interview form consisting of 4 open-ended questions was used to determine the views of academics working at universities in the 2019-2020 academic year.

Easier and more accurate information can be provided through interviews from people who have no answers to surveys or who do not find it interesting to answer a series of questions, who are more verbally successful in expressing themselves. In addition, ensuring that the respondents answer without consulting others is important in terms of protecting individuality in the answers. This enables the data source to be confirmed and its validity is higher than the data obtained through surveys (Çağlar, 2009). Also, some details that are not reflected in forms or questionnaires can be obtained during the interview.

\subsection{Structured Interview Form}

The structured interview form consists of four questions aimed at determining the necessity of distance education in the field of physical education, which courses can be given within the scope of distance education, whether applied courses can be taught through distance education and the problems they experience in the lessons in the distance education process, which is mandatory due to the pandemic.

The interview form was presented to the opinion of two instructors in the field of educational sciences with qualitative studies and expert opinion was obtained. The application was carried out between 1 June and 27 July 2020 by contacting the relevant academics first by phone call and by sending the questions via e-mail. The data obtained from the interviews were recorded in writing by the researcher.

\subsection{Statistical Analysis}

A descriptive analysis technique was used to analyze the data. Descriptive analysis is carried out to present the obtained findings in an edited and interpreted manner. Data are summarized and interpreted according to pre-determined themes (Yıldırım \& Şimşek, 2016).

In this context, the following path was followed for data analysis in the research:

1) Academics sent the interview forms, in which they recorded their opinions, to the researcher by e-mail. Interview forms were numbered and read individually, and the sentences defending the same main idea were transformed into a single thematic sentence by the researcher in a way that would not distort the meaning. A common theme was created by gathering similar views of other academics under the same theme, and their frequencies and percentages were calculated.

2) Validity and reliability phase: In the study, all the processes of the research were explained step by step and its validity was ensured. In order to increase the reliability of the classifications, the study was first classified 
separately by the researchers and then compared and given its final form. The reliability calculation of the study (Miles \& Huberman, 1994) was determined using the Percentage of Agreement Formula $[\mathrm{P}=(\mathrm{Na} / \mathrm{Na}+\mathrm{Nd}) \mathrm{x}$ 100] (P: Percentage of Compliance, Na: Amount of Compliance, Nd: Amount of Conflict). In the reliability calculation, the percentage of reliability is considered to have been reached when the percentage of compliance is $70 \%$ (Yıldırım \& Şimşek, 2016). The "percentage of compliance" of the study was found to be $93 \%$.

\section{Results}

The questions asked to the academicians and the findings obtained in order to determine "The Views of Physical Education and Sports Teaching Instructors on Education in the Covid-19 Period" are given below. Academics stated that, by the pandemic process, the courses in universities are generally carried out by using one or more of the applications such as "document uploading, video, live stream lecture, or homework". Accordingly, the opinions of the academics were asked.

Table 1. Academics' opinions regarding: Do you think distance education is necessary for the field of physical education and sports? Why?

\begin{tabular}{lll}
\hline Opinions & f & $\%$ \\
\hline No. All courses in the field must be face to face & 21 & 33 \\
Yes. Must be required by the conditions & 12 & 19 \\
May be suitable for Theoretical courses, but not suitable for practical courses & 30 & 48 \\
\hline
\end{tabular}

As shown in Table 1, 48\% of academics said that theoretical courses in physical education and sports can be given with distance education, but are not suitable for practical courses, 33\% have stated that all courses in the field should be face-to-face, and $12 \%$ have agreed that they can be done according to the conditions.

Table 2. Academics' opinions regarding: What courses do you think can be given within the scope of distance education?

\begin{tabular}{lll}
\hline Courses & f & $\%$ \\
\hline All courses can be given & 2 & 3 \\
Non-disciplinary courses can be given & 6 & 10 \\
All theoretical courses can be given & 33 & 52 \\
Some of the theoretical courses can be given & 15 & 24 \\
Theoretical courses and some applied courses can be given & 2 & 3 \\
Formation courses can be given & 3 & 5 \\
None should be given & 2 & 3 \\
\hline
\end{tabular}

As can be seen in Table 2, 52\% of the academics think that all of the theoretical courses can be given by distance education, followed by $24 \%$ of the opinion that some theoretical courses can be given. Also, $10 \%$ of academics said that non-disciplinary courses can be given with distance education, $5 \%$ have stated formation courses can be given, $3 \%$ have stated all courses can be given, and 3\% have agreed that none of the courses should be given by distance education.

Table 3. Academics' opinions regarding: How do you evaluate the applied courses being delivered through distance education? Explain the grounds

\begin{tabular}{|c|c|c|}
\hline Opinions & $\mathrm{f}$ & $\%$ \\
\hline I don't think it's right because it's inefficient. & 50 & 79 \\
\hline $\begin{array}{l}\text { It can be done in mandatory circumstances. Because rather than not doing it at all, some information would be given, at least } \\
\text { in theory. }\end{array}$ & 6 & 10 \\
\hline $\begin{array}{l}\text { It can be done. By creating a visual and video-assisted tracking system, they can repeat and record the skill in an appropriate } \\
\text { environment where they live in accordance with the guidelines given. }\end{array}$ & 6 & 10 \\
\hline Maybe for some lessons. By simulation & 1 & 1 \\
\hline
\end{tabular}

As can be seen in Table 3, the vast majority of the academics (79\%) stated that they did not find it correct to give the applied courses by distance education. However, $10 \%$ have agreed that it can be done in mandatory circumstances, and another $10 \%$ stated it could be done if necessary conditions were created. Only $1 \%$ of the 
academics stated that some courses could be given by simulation.

Table 4. Academics' opinions regarding: What kind of problems have you experienced in the courses you gave during the distance education process this semester? Explain

\begin{tabular}{lll}
\hline Opinions & f & $\%$ \\
\hline Problems caused by the inexperience of distance education & 12 & 19 \\
Problems caused by the system & 35 & 55 \\
No feedback from students & 13 & 21 \\
The courses did not reach its goal, in terms of efficiency & 23 & 36 \\
Evaluation is not efficient & 13 & 21 \\
Students participation were insufficient & 19 & 30 \\
Students without computers and the Internet had difficulty following the courses. & 11 & 17 \\
Homework not done on time and properly & 8 & 13 \\
Difficulty in reading and evaluating homework as homework is given in many lessons & 1 & 2 \\
We were unable to provide distance education due to lack of technical infrastructure & 1 & 2 \\
I've never had any problems. & 1 & 2 \\
\hline
\end{tabular}

As can be seen in Table 4, Among the 63 academicians who participated in the study; $55 \%$ of them stated that they have problems arising from the system, $36 \%$ of them have problems in terms of the efficiency of the course and $30 \%$ of them have problems related to the inadequacy of students' participation in the course. These problems are followed by the inability to get feedback from students with $21 \%$ and the problems related to assessment. While $19 \%$ of the academics stated problems caused by the inexperience of distance education, $17 \%$ of them expressed problems caused by internet and computer impossibility in their home countries, and $13 \%$ expressed problems with the delivery time and quality of homework. Only $2 \%$ of the academics stated that the problems experienced in reading the homework, the problem of not being able to provide distance education due to lack of technical infrastructure and that they did not have any problems.

\section{Discussion}

In this research, which was conducted to determine The Views of Physical Education and Sports Teaching Instructors on Education in the Covid-19 Period, when academics' answer on the question of Do you think distance education is necessary for the field of physical education and sports? $48 \%$ of academics stated that theoretical courses can be given with distance education, but practical courses are not suitable, $33 \%$ stated that all courses in the field should be face-to-face, and $12 \%$ agreed that they can be done according to the conditions. Academics who expressed the opinion that all courses should be face-to-face stated that the academic process is not only about conveying theoretical knowledge, but also the necessity to develop attitudes and behaviors required by the teaching profession and to understand the methods and techniques for application. Keskin and Özer Kaya (2020) stated in their studies on web-based distance education that $84.4 \%$ of the students expressed that distance education is not as effective as face-to-face education (Keskin \& Kaya, 2020).

Higher education has a dominant power for education at all levels, and in this respect, students' experiences in higher education are very important in terms of teaching and learning practices (Knapper \& Cropley, 2000). In a study conducted by Horton (2000), it was found that almost every learning activity used in a face-to-face teaching environment can be used in distance education. Also, it was stated that many teaching methods and techniques such as presentation, discussion, demonstration, question and answer, brainstorming, case study, collaborative learning, problem-based learning can be used (Horton, 2000). However, when we look at these methods and techniques, it can be said that it is for the teaching of knowledge based on theoretical and mental learning, but distance education will be incomplete in the teaching of applied courses.

In the research, academics were asked which courses can be given within the scope of distance education, $52 \%$ of academics reported that all theoretical courses and $24 \%$ of some theoretical courses could be given. Some academics express that non-disciplinary courses, formation courses or all courses can be given, as well as academics who express that none of the courses can be given. Academics who expressed that some theoretical courses can be given also noted that if the course includes practical parts as well as the theoretical part, then it should not be given in distance education.

It has been stated that web-based distance training may succeed in the information and grip of Bloom Taxonomy, but not enough in the steps of application, synthesis, analysis, and evaluation (Forehand, 2010). In a study conducted on students on web-based distance education, when distance education was evaluated over 10, its contribution to theoretical knowledge level was found to be $4.07 \pm 2.42$, and its contribution to professional 
practice skills as $2.48 \pm 1.98$ (Keskin \& Kaya, 2020). In a study, 10 out of 32 students, ie approximately $31 \%$, stated that distance education is efficient for theoretical courses (Altun, 2020). In our research, $52 \%$ of the academicians had the view that all of the theoretical courses could be given in distance education, and the $31 \%$ of the students in Ekiz's (2020) study stated that distance education is suitable for theoretical courses, findings of both studies support each other. However, it is thought that the fact that very different opinions were expressed in our study could be since there was not a high level of consensus in this period of emergency distance education, which could not provide a level of course flow that would satisfy both academics and students, depending on many factors. Since some academicians believe that all theoretical courses or some theoretical courses and non-field courses can be taught by distance education, it can be said that, in case of necessity, with good planning and use of correct methods and techniques, the theoretical part of the courses can be given within the scope of distance education.

To the question of how do you evaluate the delivery of applied courses through distance education, $79 \%$ of the academicians stated that they are not suitable and that the applied courses will not reach their real purpose. On the contrary, $10 \%$ stated that conditions can be created and given these courses, while $10 \%$ expressed that they can be given with distance education in compulsory conditions such as Pandemic. The study conducted by Altun Ekiz (2020) supports the conclusion of this research that it is not appropriate to conduct the applied courses through distance education. In the study conducted by Ekiz (2020), 28 out of 32 students stated that distance education is inefficient for applied courses (Ekiz, 2020). These results show that the majority of academics and the students agree on this issue. Tria (2020) stated that performance-requiring laboratory activities such as physical education and arts will be limited to written exams in distance education, and performance evaluation will be difficult (Tria, 2020). Keskin and Özer Kaya (2020), stated that students' trying to comprehend information only without applying, may cause them to forget the subjects quickly (Keskin \& Özer Kaya, 2020).

In this pandemic period, the applied courses that are tried to be carried out within the scope of distance education do not reach their purpose and negatively affect the professional competence of teacher candidates in terms of gaining both professional knowledge and technical skills related to the field. Teaching is a phenomenon that has principles, standards, and practices. Erden (1998) emphasized that teaching skills are not innate and can be done by those who know the field (Erden, 1998). Three main competencies are aimed to be acquired in teacher training programs: field knowledge, professional knowledge, and general culture (Aydın, 2007). Another process that is integrative of these three main features and plays a critical role in terms of professional competence is applications. Pre-service practices are very important for the teaching profession. During these practices, teacher candidates learn to recognize the learning and development characteristics of children, to recognize and meet their individual and special needs, to organize their learning life well, to be aware of the problems they may encounter during the education process, and to follow their own professional development (Tok, 2011). In this respect, practices related to both profession and field knowledge should not be ignored, and the deficiencies due to obligation should be tried to be covered by make-up lessons.

In the research, regarding the question of what kind of problems you have experienced in the courses you give in the distance education process this semester, 55\% of the academics are with the system, $36 \%$ with the course efficiency, $30 \%$ with the class participation rate, $21 \%$ do not get feedback from the students, and again $21 \%$ expressed the problems arising from not being healthy. While $19 \%$ expressed problems arising from the inexperience of distance education, $17 \%$ stated that the problems caused by the internet and computer impossibilities in the environment where students live negatively affected the lessons. It was observed that $13 \%$ of the academics had problems with the quality and timely delivery of the homework given to students. However, while there are academics who cannot provide distance education due to the lack of infrastructure, there are some who do not have any problems since the infrastructure in their universities is very good in this process.

It is stated that with the many types of interactions integrated into distance education, it is very difficult to provide a quality distance education that meets the needs and that preparations can take months (Canpolat \& Narin-Canpolat, 2020). Additionally, to realize effective teaching in distance education, educators need to be knowledgeable in the areas of communication and effective feedback, management, support, and service, to work in teams, to know how to do needs assessment, to know learning technologies well and to have the competencies to show a certain point of view on their effects on learners (Dabbagh \& Ritland, 2005). Due to the pandemic, compulsory distance education has become inevitable in our country, as in the whole world. In a very short time, all educators and students, who do not have competence in the field of distance education, found themselves in this system. As all education system caught off guard, problems are inevitable. Problems arising from inexperience in distance education are expressed by $19 \%$ of the academicians. Similar to the academics who stated that they mostly experienced problems stemming from the system; Studies are showing that errors 
arising from the system such as system logging problems (Ekiz, 2020), technical problems from time to time in lessons (Yılmaz \& Güven, 2015; Keskin \& Kaya, 2020), technical problems are the leading factors that negatively affect their perceptions, disconnection, screen freezing. The reverberation of sound causes negative perceptions in students (Karal et al., 2011). In our research, 55\% of the academicians stated these problems, and in Keskin and Özer Kaya's (2020) study approximately $54 \%$ of the students stated the same problems. Based on similar rates, it is thought that all kinds of technical problems related to the system will negatively affect both academics and students at the same level, reducing interest and motivation in the courses, and negatively affecting the level of learning and participation in the next lesson.

The importance of the technical infrastructure in terms of distance education is indisputable. However, quantitatively no matter how good everything is, it is not enough by itself. It is a fact that quality is very important in learning. Also, students stated that they were worried about quality (Kaur \& Wati, 2004). This suggests that they could not get the efficiency they expected from courses. Similarly, in another study, the majority of the students stated that the lessons were inefficient (Ekiz, 2020). These findings coincide with the views of academics. In the distance education process, it can be said based on the findings and other research results that the expected level of efficiency cannot be obtained from education.

Students' participation is extremely important in the course in order to get the desired level of efficiency from education. However, in our research, $30 \%$ of the academics stated that participation was low in the courses. In a study, approximately $34 \%$ of the students stated that they could not attend classes regularly (Ekiz, 2020). It is a fact that students' irregular participation in courses affects academicians' preparation and lecture processes negatively, and that will affect students learning levels. In this respect, conditions should be created for the participation of students in the distance education process.

Failing to get feedback from students was among the problems that negatively affected academics in this process. There are also findings that faculty members stated that they do not receive feedback from students during distance education and that this affects their motivation negatively (Topu et al., 2011). These findings support our research. Getting feedback is a way of communicating for both academics and students. It is thought that good communication is very important for learning, and timely feedback will have a positive effect on the course flow. When we consider distance education in terms of communication, studies have shown that students cannot comfortably communicate with their instructors (Ekiz, 2020; Keskin \& Kaya, 2020) and they expressed that they could not find the opportunity to ask questions (Y1lmaz \& Güven, 2015; Ekiz, 2020). These situations lead to a negative perception of distance education and will create a disadvantage in terms of this education model.

In the research, the academicians stated that they had problems in evaluation. This problem was expressed in the form of not being able to evaluate the course appropriately, not to evaluate the application performance, to evaluate only through homework, and not to prevent cheating. Academicians stated that the average success of the students in general increased in this process. In addition, it was stated in a study that the class average increased at varying rates in most of the exams conducted in the digital environment (Solak et al., 2020). This supports doubts about cheating. Similarly, in another study, faculty members stated that they felt obliged to make a uniform assessment, and this situation prevented a healthy evaluation (Topu et al., 2011). When evaluating the distance education process by considering the opinions, making the most appropriate assessment practices for the type of the lesson, its content, and the way the lesson is taught. However, in order to do these, it is considered necessary for academicians to learn alternative assessment methods that can be applied within the scope of distance education. As stated by the academicians, another problem that needs to be addressed is internet access and computer problems. In a study conducted on education in the Covid-19 pandemic, the problem of students' internet access, sharing a single computer in some families, or no computer in the family were mentioned (Olmos-Gómez, 2020). In another study, 6 out of 32 students could not attend classes because they do not have internet (Ekiz, 2020). And in another study, it was stated that students needed technical and technological support and were negatively affected because this support was not provided (Doğan \& Tatık 2015).

In our research, $17 \%$ of the academicians stated that their students had problems in attending classes due to internet and computer impossibilities, and this was a problem that negatively affected their course flow. No matter how well you prepare distance education in terms of quantity and quality, in cases where there is no internet and computer in the environment of the students, the education never reaches its goal because students will not be able to participate in the course. It has been reported that in web-based learning, students can provide higher interaction, increase learning success, and provide better performance with student participation (Lai \& Tho, 2019). During the pandemic process, free internet was given to university students by the Council of Higher Education within the scope of distance education activities in Turkey. Students can access the contents of their universities at https://yokdersleri.yok.gov.tr and benefit from the support quota for 6 GB distance education, 
which will be defined free of charge by mobile operators (YÖK, 2020). However, according to the opinions of the academicians, the internet alone is not enough because this quota does not reach all students or some students do not have a computer.

When the findings of the study are considered as a whole; Giving practical courses through distance education is insufficient and inefficient. It is considered that it would not be appropriate to give theoretical courses through distance education, except for necessity.

As a result; Teachers are important for individuals in the short term, but they are important for society in the long term. In addition, teachers are individuals who develop themselves, construct knowledge, educate and support their students by taking into account the characteristics of the culture they live in and the requirements of the age, as well as providing information, as a model for students with their attitudes, emotional reactions, and various habits (Zembat, 2015). The task of training teachers, who are irreplaceable for countries, is the responsibility of the Education faculties. Therefore, faculty education programs and offered courses have to be prepared and applied very accurately. For this to happen, it is important that all conditions are prepared in the best way for both academics and students. It is a fact that conditions affect the quality of education. In this respect, distance education will be inevitable in current and future epidemics such as the Covid-19 pandemic. Under these conditions, it is thought that improving technical and technological facilities, providing academicians and students with distance education seminars to use the system efficiently, providing information to academicians about alternative applications that can be used for courses and exams, providing computer and internet support to all students in need, providing applied courses in the field unless required, and providing compulsory participation to the course by using the best possible methods and techniques are required to ensure education in the most efficient way.

\section{References}

Alkan, C., Doğan, H., \& Sezgin, İ. (1991). Principles of Vocational and Technical Education. Gazi University Publication, No:170, Ankara.

Altun, E. M. (2020). Views of the School of Physical Education and Sports Students on Distance Education During the Quarantine Period (a qualitative research). Journal of Sport and Recreation Researches, 2(SI1), $1-13$.

Aydın, R. (2007). Train Made in the relevant scientific meetings in Turkey and discussed the National Education Council Ministry of National Education with Teacher Issues Policy and Evaluation of Applications (1980-2004). Ankara University Graduate School of Educational Sciences, Unpublished Doctoral Thesis, Ankara.

Çağlar, A. (2009). Investigatıon of Attentıon Taking and Keepıng Behavior of Elementary School Teachers of Teachiing Actıvitıes. Published Postgraduate Thesis, Çukurova University, Adana.

Canpolat, U., \& Narin-Canpolat, Z. (2020). The concept of e-readiness in the context of distance education irdelenmesi. Journal of Open Education Applications and Research, 6(3), 79-91.

Çiftçi, S. (2016). High School Teacher Views on Facebook Use Teacher and Student Dimension. Journal of Theory and Practice in Education, 12, 286-307.

Crawford, J., Butler-Henderson, K., Jurgen, R., Malkawi, B. H., Glowatz, M., Burton, R., ... Lam, S. (2020). COVID-19: 20 countries' higher education intra-period digital pedagogy responses. Journal of Applied Learning \& Teaching, 3. https://doi.org/10.37074/jalt.2020.3.1.7

Dabbagh, N., \& Bannan-Ritland, B. (2005). Online learning: Concepts, strategies, and application. Prentice Hall.

Doğan, S., \& Tatık, R. Ş. (2015). Evaluation of distance education program in MarmaraUniversity according to the views of students. Route Educational and Social Science Journal, 2(1), 247-261. https://doi.org/10.17121/ressjournal.187

Erden, M. (1998). Introduction to the teaching profession. İstanbul: Alkım Publications.

Ersoy, A. (2014). I Was Not Aware I Plagiarized from Online Resources: A Phenomenological Research Araştırması. Pamukkale University Journal of Education, 35, 47-60. https://doi.org/10.9779/PUJE654

Filiz, K. (2004). Habits of Reading and Research on their Profession of the Students in Gazi University School of Physical Education and Sports. Gazi Journal of Educational, 24(2), 231-242.

Forehand, M. (2010). Bloom's taxonomy. Emerging Perspectives on Learning, Teaching, and Technology, 41(4), 
$47-56$.

Gökçe E. (2004). Student and Teacher Views on Active Learning Process in Primary Education. Akdeniz Journal of Educational, 1, 53-64.

Horton, W. (2000). Designing web-based training. NY, Chichester, Weinheim, Brisbane, Singapore, Toronto: John Wiley.

Karal, H., Çebi, A., \& Turgut, Y. E. (2011) Perceptions of Students Who Take Synchronous Courses through Video Conferencing about Distance Education. Turkish Online Journal of Educational Technology (TOJET), 10(4), 276-293.

Kaur, K., \& Zoraini, W. A. (2004). An assessment of e-learning readiness at Open University Malaysia (pp. 1017-1022). In International Conference on Computers in Education.

Keskin, M., \& Özer, K. D. (2020). Evaluation of Students' Feedbacks on Web-Based Distance Education in the COVID-19 Process. İzmir Kâtip Çelebi University Faculty of Healt Sciences Journal, 5(2), 59-67.

Knapper, C. K., \& Cropley, A. J. (2000). Lifelong Learning in Higher Education. London: Kogan Page.

Lai, C. H., Lin, H. W., Lin, R. M., \& Tho, P. D. (2019). Effect of peer interaction among online learning community on learning engagement and achievement. International Journal of Distance Education Technologies (IJDET), 17(1), 66-77. https://doi.org/10.4018/IJDET.2019010105

Miles, M. B., \& Huberman, A. M. (1994). Qualitative Data Analysis (2nd ed.). Newbury Park, CA: Sage.

Olmos-Gómez, M. C. (2020). Sex and Careers of University Students in Educational Practices as Factors of Individual Differences in Learning Environment and Psychological Factorsd uring COVID-19. International Journal of Environmental Research and Public Health, 17(14), 5036. https://doi.org/10.3390/ijerph17145036

Pavon, D. J., \& Baeza, A. C. (2020). Physical exercise as therapy to fight against the mental and physical consequences of COVID-19 quarantine: Special focus in older people. Progress in Cardiovascular Diseases, 63, 386-388. https://doi.org/10.1016/j.pcad.2020.03.009

Solak, H. İ., Ütebay, G., \& Yalçın, B. (2020). Comparison of Distance Education Students' Exam Success in Print and Digital Media. Journal of Open Learning Applications and Research, 6(1), 41-52.

Tok, H. (2011). Clinical Practice in Teacher Training. Gaziantep Üniversitesi Sosyal Bilimler Dergisi, 10(4), $1363-1375$.

Topu, F. B., Baydas, Ö., Demirel, T., \& Karaman, S. (2011). Role Changes of Faculties in The Transition from Face to Face to Distance Teaching. Ietc - May 25-27, İstanbul, Turkey.

Tria, J. Z. (2020). The COVID-19 Pandemic through the Lens of Education in the Philippines: The New Normal. International Journal of Pedagogical Development and Lifelong Learning, 1(1), ep2001. https://doi.org/10.30935/ijpdll//8311

UNESCO. (2020). COVID-19 Educational Disruption and Response. Retrieved from https://en.unesco.org/covid19/educationresponse

World Health Organization (WHO). (2019). Retrieved October 8, 2020, from https://www.who.int/emergencies/diseases/novel-coronavirus-2019

Yıldırım, A., \& Şimşek, H. (2016). Qualitative research methods in the social sciences. Ankara: Seçkin Yayincilik.

Yildiz, S. M. (2007). Factors Affecting the Quality of Educational Services at Schools of Physical Education and Sports. Kastamonu Journal of Education, 15(1), 451-462.

Yılmaz, G. K., \& Güven, B. (2015). Determining the Teacher Candidates' Perceptions on Distance Education by Metaphors. Turkish Journal of Computer and Mathematics Education (TURCOMAT), 6(2), 299-322. https://doi.org/10.16949/turcomat.75936

YOK. (2020). $\quad$ Retrieved $\quad$ August $19, \quad$ 2020, https://www.yok.gov.tr/Sayfalar/Haberler/2020/ogrencilere-egitime-destek-kotasi.aspx

Zembat, R. (2015). Teacher in the education system (Editör: A. Oktay: Introduction to Educational Science, pp. 277-302). Ankara: Pegem Akademi Yayıncilık. 


\section{Copyrights}

Copyright for this article is retained by the author, with first publication rights granted to the journal.

This is an open-access article distributed under the terms and conditions of the Creative Commons Attribution license (http://creativecommons.org/licenses/by/4.0/). 